\title{
ROMANIAN Hos(TI)PITALITY IN TRANSLATING JOYCE
}

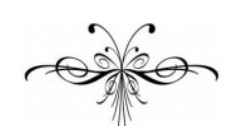

ARLEEN IONESCU

\begin{abstract}
Starting from the ambivalent notion of hospitality, combining both the guest to be welcomed and the host, and Derrida's coinage of 'hostipitality', a concept which recaptured the inimical alterity between hospitality and hostility, the article explores a very specific host: the Romanian translator, whose house is the Joycean text and whose guest is the Romanian reader. With the help of Antoaneta Ralian's reflections on censorship, my essay explores the "task" of the Romanian translators Frida Papadache and Mircea Ivănescu in the communist age, more precisely what they had to give up (in the other sense of Benjamin's "Die Aufgabe des Übersetzers"). Thus, I am looking into how some of Joyce's passages from A Portrait of the Artist as A Young Man and Ulysses, especially those imbued with religious, political or sexual connotations, were changed by the translators in line with the ideological and political background of communist Romania in order for both Joyce's text and the translator's creation to 'live on'.
\end{abstract}

Keywords: Censorship; Hospitality; Hostility; James Joyce; Translation.
Resumo: A partir da noção ambivalente de hospitalidade, que congrega tanto o convidado a ser recebido como o seu anfitrião, e a cunhagem de Derrida de "hostipitalidade", um conceito que recapturou a alteridade hostil existente entre a hospitalidade e a hostilidade, este artigo explora um anfitrião muito específico: o tradutor romeno, cuja casa é o texto joyceano, e cujo convidado é o seu leitor. Com a ajuda das reflexões sobre censura de Antoaneta Ralian, este ensaio explora a "tarefa" dos tradutores romenos Frida Papadache e Mircea Ivănescu durante a era comunista, mais precisamente o que tiveram de abandonar (no outro sentido do "Die Aufgabe des Übersetzers" de Benjamin). Desse modo, dirijo meu olhar para como algumas das passagens de Joyce em A Portrait of the Artist as A Young Man e Ulysses, particularmente aquelas impregnadas de conotações religiosas, políticas ou sexuais, foram alteradas pelos tradutores em conformidade com o pano de fundo ideológico e político da Romênia comunista, com o fim de que tanto o texto de Joyce quanto suas criações tradutórias pudessem "permanecer vivos apesar das dificuldades".

Palavras-chave: Censura; Hospitalidade; Hostilidade; James Joyce; Tradução. 


\section{ARLEEN IONESCU}

Then young Stephen Dedalus thinks of God in A Portrait
of the Artist as a Young Man, he is overwhelmed by
God's power of understanding and "thinking big". The almighty God knows all names and speaks all the languages of the world, since he created the world. He is the perfect host to any guest:

God was God's name just as his name was Stephen. Dieu was the French for God and that was God's name too; and when anyone prayed to God and said Dieu then God knew at once that it was a French person that was praying. But, though there were different names for God in all the different languages in the world and God understood what all the people who prayed said in their different languages, still God remained always the same God and God's real name was God. ( $P$ 15)

Irrespective of the number of 'doors' or linguistic thresholds to his home - and here we should recall that "Babel" also means $\mathrm{bab} \mathrm{El}$ : the gate of God the Father - this God is the perfect master of the house, who waits for his guests in front of all doors, listening to each and fulfilling their wishes in their respective languages.

\section{Hosts and Guests in Translation}

Starting from the assumption that people cannot "think big" like God, as Stephen puts it, this article will explore a very specific host: the Romanian translator, whose house is the Joycean text and whose guest is the Romanian reader. Apart from my debt to Benjamin's crucial "The Task of the Translator" and to the Derridian notion of "hostipitality", I will also resort to Lawrence Venuti's theories of "foreignization" and "domestication".

Walter Benjamin's epoch-making essay "The Task of the Translator" lays the foundation for hospitality in translation. On the threshold of translation, the master of the house - the translator - has to extend his own language towards the limits of a "pure language" (reine Sprache).

Hospitality is ambivalent since it combines both the guest to be welcomed and the host, the master of the house who can impose his will as a despot and thus turn into an enemy (Latin hostis) - an ambivalence still recorded for example in the French word hote: at once the guest and the host (Benveniste, $1969,94)$. Derrida coined the notion of 'hostipitality' in order to recapture the inimical alterity between hospitality and its parasite, hostility. As Derrida put it, when we welcome somebody near our door, "for there to be hospitality, there must be a door. But if there is a door, there is no longer hospitality. There is no hospitable house. There is no house without doors and windows. But as soon as there are a door and windows, it means that someone has the key to them and consequently controls the conditions of hospitality" (Derrida, 2000, 14).

According to Venuti, the act of translation inevitably communicates the foreign text in the domestic terms of the host country, but the domestic inscrip- 


\section{ROMANIAN Hos(TI)PITALITY IN TRANSLATING JOYCE}

tion also needs to include a significant part of the foreign context (Venuti, 2002, $501)$.

Many scholars have emphasized the difficulty of translating Joyce's texts into any language. Among the major hurdles awaiting the translator, $\mathrm{Pa}$ trick O'Neill mentioned "the pervasive indeterminacy of his works, the densely textured structural and verbal networks that inform them, the encyclopedic employment in them of every imaginable variety of paronomasia, witticism, rhethorical device, and word play, a pervasive allusiveness to a highly specific and densely textured cultural matrix" (O'Neill, 2005, 71). And indeed the most challenging episodes to translation in any language were experimental episodes such as "Sirens" and "Oxen of the Sun" in Ulysses, not to mention the "Wakese' of Finnegans Wake.

Romanian translators had to face one more difficulty in translation, since Joyce's major texts in Romanian appeared during the long rule of dictator Nicolae Ceauşescu, in an age dominated by intolerance and xenophobia. In 1966 Frida Papadache translated Dubliners (Oameni din Dublin) and in 1969 A Portrait of the Artist as a Young Man (Portret al artistului la tinerețe); Mircea Ivănescu translated Ulysses in $1984^{1}$ after partially serialising it in the least politicised literary journal of the communist era, Secolul XX: "Oxen of the Sun" (1971), "Hades" (1973), "Aeolus" (1977), "Cyclops" (1982). At present, there is still no complete Romanian translation of Finnegans Wake; only parts of the "Anna Livia Plurabelle" chapter were translated by Felicia Antip (1996) and by Laurent Milesi (1998), which will not be included in this study as they appeared after 1989, when there were no longer censorship committees or agencies.

It may seem paradoxical to attempt to connect those existing Joycean translations to the Derridian notion of (absolute) hospitality, since the act of hospitality which consists in translating a foreign author took place in a country and in an age harbouring all the premises against hospitality. If we were to give another name to this age of deprivation, ironically called "the golden age" (epoca de aur) but in fact one of the darkest ages in Romanian history, it would rather be hostility "itself".

In 2003 Vladimir Tismăneanu published his excellent study Stalinism for All Seasons, which meticulously documents the metamorphosis of a 1920s tiny, clandestine revolutionary organization named the Communist Party into the many-faceted monster that curbed all intellectual freedom till its downfall in the 1989 Revolution - and whose ghost still lingered on in the post-1989 reincarnations of its former nomenclature. According to Tismăneanu, behind "the "national hero' celebrated by the official media", Ceauşescu was nothing but an "apparatchik", "a prisoner of his own myth [...] led by a chain of psychoemotional identifications to believe that he embodied historical rationality" (Tismăneanu, 2003, 217). The famous 2006 report of the Presidential Commission for the Study of the Communist Dictatorship in Romania ${ }^{2}$, chaired by Tismăneanu himself, unequivocally incriminates the participants in the cultural life who actively supported the Communist regime and created

\footnotetext{
${ }^{1}$ In this article I will quote from the second edition of this translation (published in 1996).

${ }^{2}$ In 2006 Romania was the first country in Europe to reconcile with history through a presidential speech in the Romanian Parliament and to condemn the infamous "golden age".
} 


\section{ARLEEN IONESCU}

"platforms for manipulative pseudo-nationalism during the late years of Ceauşescu's regime" (see Tismăneanu \& all, 2006, 633).

Many critics hold the view that in totalitarian states, modes of expression which would have never been allowed for a native were permitted to an author in translation. One could enlist a few instances, such as "the sporadic thaws of post-Mao China and late Franco Spain" (see Bamstone, 1993, 123), when foreign authors in translation escaped bowdlerization because the restrictive system of censorship was somehow forced to relax, or the translations in 1930s Italy before Mussolini's regime considered that they should not seem "too receptive to foreign influences since excessive receptivity would imply a failure on the part of the fascist revolution to create a culture of its own" (Rundle, 1999, 427).

In the second edition of The Routledge Encyclopedia of Translation Studies, the author of the chapter on Romanian translation, János Kohn, claims rather hastily that in Ceauşescu's time, while original literary works were subjected to censorship and were brought out only provided they glorified the Romanian president and his communist regime, "translation was regarded as an ethically sound activity" (Kohn, 2009, 516) (He also states, more correctly, that many authors refused to write their original works "on literary or moral grounds", preferring to sign translation contracts with publishing houses.). More careful distinctions should be made here: between the 1960s and 1989, there were different degrees of censorship and the latter was not always considered to be threatening towards every artistic work that challenged the regime's ideology. In his excellent study on communism, Literatura română sub communism, Eugen Negrici divides the Romanian culture and especially literature during communism into three main periods: the Stalinist age (what Negrici calls proletcult$i \mathrm{sm}^{3}$ ) between 1948-1964, the age of liberalization and cultural opening (19641971), and the period of degradation, when Ceauşescu implemented a distinctly home-grown version of communist ideology (1971-1989). This tripartite classification can be mapped on to comparable attitudes towards the acclimatization of foreign texts via translation.

The first period was characterized by a cultural annihilation of the foreign, when any influence from the West was nipped in the bud and stifled by the Stalinist flavour of Marxist ideology, when translations from Western countries were not possible and when even translations of classical texts were contaminated by Marxism (for instance Hamlet, which was read through the crude Marxist lens of "historical progress" as an "optimistic tragedy" in which the new order defeats the old reactionary one). By the beginning of the second stage, after Gheorghiu-Dej's death in 1965 and Ceauşescu's accession to the leadership of the Communist Party, the communist regime had stabilized its position. In order to ingratiate himself with the West and consolidate his regime, he soon made a gesture unprecendented in any other communist country: the condemnation of the Soviet army's invasion of Czechoslovakia in May 1968. At

\footnotetext{
${ }^{3}$ The term is translated from the Russian term proletkul'tovshchina, meaning both a cultural trend that referred to rejection of the cultural heritage and the formation of a new form of culture, exclusively dedicated to the proletarians, and the general attitude towards arts after the October Revolution in both the Soviet Union and the Eastern European states in which the formation of a purely proletarian culture was the new ideal.
} 


\section{ROMANIAN Hos(TI)PITALITY IN TRANSLATING JOYCE}

the beginning of his political career he brought his own softer version of Stalinist "scientific materialism" that had dominated Dej's "revolutionary conquests." The cusp between the sixties and the seventies was therefore a period when translations suffered from a lesser degree of censorship. James Joyce, Mark Twain, Walt Whitman, Edgar Allan Poe, Ernest Hemingway, William Faulkner were soon translated by some of the most prolific Romanian translators, among whom Frida Papadache, Petre Solomon, Petru Comarnescu, Eugen B. Marian, Emil Gulian, Dan Botta, and Mihu Dragomir.

But the communist regime gradually realized that translations could be turned into deliberate manipulations of the original, tools re-engineered in order to control behaviour and expose the mercantilism, corruption, and lack of morality of the Western enemy. The turning point was 1971, when the Council of Socialist Culture and Education (Consiliul Culturii şi Educaţiei Socialiste: $C C E S$ ) was set up with a view to bringing anything remotely smacking of culture under ideological control: the thematic remit of museums, theatre repertoires, book proposals and the number of printed copies when published, the production and distribution of films, etc. Fundamental human rights were trampled underfoot one after the other: freedom of speech, religious freedom,,freedom of movement (people could no longer leave the country). Ceauşescu began to publicly attack the Romanians" "inconsistent practice" of looking at what was being produced in Western countries. The ruler's main purpose was to show that Romanians were superior to other nations on account of "their ancient roots (their territory was the very cradle of Indo-Europeans), of tolerance (they offered, through Antonescu ${ }^{4}$, a human treatment to the Jews) and of incomparable historical intuitions (having the vocation of uniting around their leader)" (Negrici, 2003, 61, translation mine).

Other Romanian commentators on the political background in which Joyce's Ulysses appeared, alongside many other translations from Western authors, share my opinion that censorship was exercised on translations as well, in the spirit of what the communist leaders called "democracy". Critic Geta Dumitriu gave a whole list of Joyceans who, from the early seventies onwards, had to seek hospitality in other countries, and for whom exile was the only way of escaping the communist regime: Simona Drăghici, Constantin George Săndulescu, Rodica Kereaski, Andrei Brezianu, Ştefan Stoenescu (see Dumitriu, 1997, 199). That same year Bogdan Ştefănescu's own review of Ulysses in Romanian mentioned the "animal state to which the communist state would have its subjects reduced through hunger, hopelessness, and humiliation", and regarded the translations as "rare and miraculous instances of texts that had made it through the security of thought" (Ştefănescu, 1997, 15). In his 2004 essay on the reception of Joyce in Romania, Adrian Oţoiu pointed out how Romania had become a "Soviet satellite" whose main role was to spread its official antiWestern policy: "[e]very departure from the dogma of strict socialist realism was stigmatized as 'escapism', modernist experiment was branded as 'formal-

\footnotetext{
${ }^{4}$ Ion Antonescu was the Romanian leader during WW2, who was promoted to Marshal of Romania and who (according to the communists) was said to have been very human to the Jews during the war. In reality, the communists were just re-rewriting history, as Antonescu was responsible for mass deportation of Bessarabian and Ukrainian Jews, as well as the Jews from Moldavia and Gypsies from Romania.
} 


\section{ARLEEN IONESCU}

ism' and the key names of modernism were purged from university syllabi and ousted from critical debate. On the rare occasions they were mentioned, writers such as Joyce and Kafka were pilloried as embodying decadent art and so-called "petty bourgeois individualism"' (Oţoiu, 2004, 199-200). More recently, Rodica Ieta gave a brief account of the Romanian "socio-political agenda" through which Ulysses was read in the eighties (Ieta, 2007, 124).

In context, I will draw on a few recent confessions from a prolific Romanian translator, Antoaneta Ralian (born in 1924), who did not translate Joyce in those days but (re)translated A Portrait of the Artist as A Young Man in $2012^{5}$, bearing in mind the fact that the Romanian language evolved significantly since Portretul artistului la tinereţe appeared in 1969, and was reprinted in 1987 and 1995 without any revision ${ }^{6}$.

In an interview published in May 2011, Antoaneta Ralian, the translator of no less than 113 books from authors such as D.H. Lawrence, Saul Bellow, Iris Murdoch, Salman Rushdie, Amos Oz, Tennessee Williams and Henry Miller, gives an account of her jobs as a member of several censorship committees during Ceauşescu's time: the first task was to remove from public libraries all books that were regarded as subversive: books that were seen as either anticommunist, anti-socialist or downright pro-capitalist, as well as religious, erotic or mystical books. Against her own education and convictions, she made reports to take Kant, Leibniz and Nietzsche off the shelves. Through some ironic quirk of history, she also removed Henry Miller, whose whole trilogy The Rosy Crucifiction (Sexus, Plexus, Nexus) she ended up translating some fifty years later. Her next job as a worker in The Press General Directorate (Direcţia Generală a Editurilor) was to compile statistic and thematic reports on foreign literatures, and to make yearly as well as five-year plans (the famous communist planuri cincinale). ${ }^{7}$ All publishing houses sent their manuscripts to the highest censorship institution, Direcţia Presei (Press Control Agency). Some of the manuscripts did not find their way back to the publishing houses, others were cut drastically, and others still came back for a facelift with big question marks in the margins. Another position Antoaneta Ralian held was in the department named "Self-censorship", where she would intervene on texts before sending them to the high Direcţia Presei. As she reveals to the perplexed reader of her interview: "I would delete words, I would transform others, I would diminish, I would use periphrasis, whatever, I would blur" (Ralian, 2011, translation mine). Antoaneta Ralian's story goes into details that show how the most insignificant scenes from different British authors were expunged for fear they might allude to the Ceaşescus in some way. For instance, she had to excise a fragment from Thackeray, even though, to any sane mind, a nineteenth-century novel should be proof enough that the Ceaussescus could not possibly have been targeted. The incriminated fragment was the description of a sailor who had a monkey that

\footnotetext{
${ }^{5}$ On this occasion, I hail this translation which was more than necessary, yet, taking into account that my article deals with translation under censorship I will not analyse Ralian's latest translation of $A$ Portrait here.

${ }^{6}$ In this article examples from Papadache's translation will be taken from the 1987 edition.

${ }^{7}$ In a previous interview, she relates that the normal distribution of the books would be: books on agriculture, books on textiles, books praising the alliance between workers and peasants, the great achievement of socialism and the last and almost recluse corner of these plans: translations from universal literature (see Ralian, 2007).
} 


\section{ROMANIAN HoS(TI)PITALITY IN TRANSLATING JOYCE}

was said to have travelled around the world. At that time, the Ceauşescus were travelling round the world; one of most hilarious of the underground jokes about the couple was aimed at Elena Ceauşescu's lack of culture (she used to make huge grammar mistakes, very often being unable to make the correct agreement between subject and predicate): "Is there more states to see, your Major-state?" The joke would refer to her, apparently addressing her husband as "Your Majesty" ("Maiestate"), but in fact saying "Mai e state de văzut?" (literally: Is there more states to see?).

This was the "golden age" of censorship, when these surgical treatments were performed by people with education, who could still hide some meaning behind metaphors. However, by the eighties, intellectuals like Antoaneta Ralian no longer had "healthy credentials" (to translate the symptomatic Romanian idiom a nu avea origini sănătoase). Authorities soon discovered that her husband was a former collaborator of Iuliu Maniu, cofounder of the Peasants' Party, outlawed in July 1947, who was to die in 1953 in a Romanian communist prison and sent her to a publishing house.

In another interview, Ralian reflects back on her "task" as a translator, more precisely on what she had to give up (in the other sense of Benjamin's title "Die Aufgabe des Übersetzers") in her own translations of different British and American authors: in Lawrence's Sons and Lovers a whole episode with a homosexual resonance, rewritten into a platonic relation, and in Bellow's Humboldt's Gift an essay on the boredom of socialism ${ }^{8}$ (see Duca, Ralian, 2010).

Given what compromises translators had to make in order to steer their work to publication through several hurdles of authorizing committees in such a hostile environment, it is very hard to appreciate the craft of the translator, whose task was to re-write the Romanian version to the liking of the eagle-eyed censors. It is equally hard, if not impossible, to assess how acquainted Joyce's main translators (Frida Papadache and Mircea Ivănescu' ${ }^{9}$ ) were with Joyce's sources as well as with the available scholarship, whether they had access to annotated editions of Joyce's short stories and novels, as well as to comprehensive dictionaries. Papadache's translation of Dubliners [Oameni din Dublin] is prefaced by Dan Grigorescu (a Joycean scholar who is the only author of a Romanian Joycean biography) and the first edition of Portret al artistului în tinereţe (1969) has a Cuvânt înainte al traducătoarei [Translator's Introduction] which disappeared without a trace in the second edition (1987). The very few sources mentioned in Portret al artistului mention, apart from Richard Ellman's biography and Levin's The Essential James Joyce, only French sources, and show Papadache's constant attempt to bring her translation of Joyce in line with Valery Larbaud's. Ivănescu opted for glossing his translation heavily and acknowledged his debt to Gifford and Seidman's An Annotation of James Joyce's Ulysses, Zack Bowen's Musical Allusions in the Works of James Joyce, Darcy O'Brien's The Conscience of James Joyce, and Joseph Prescott's James Joyce, Configuration Critique. He also mentions the

\footnotetext{
${ }^{8}$ All the censored passages were restored to the editions published after 1989.

${ }^{9}$ Both translators died and left no traces of their work on the translations they published, except a few scattered remarks on several difficult passages.
} 


\section{ARLEEN IONESCU}

correspondence between Pound and Joyce as well as Richard Ellmann's biography as sources of inspiration.

In my endeavour to establish a few inhospitable ways of rendering Joyce in Romanian I will therefore look mostly at those ideologically sanctionable areas like religion, politics, and sex that translators had to hide or tone down, the sine qua non condition for their work to be publishable.

\section{Filtering Joyce's Religion and Politics}

In his brief analysis of Romanian translations of Joyce's works, Adrian Oţoiu pointed out a few changes that would suggest Frida Papadache's "anticlerical intervention" on Dubliners, whereby "Catholic gesture is muffled to a mere 'large gesture', 'that Rosicrucian' becomes 'these pious ones', while 'simoniac ${ }^{10}$ is suppressed altogether" (Oţoiu, 2004, 201). While I would generally agree with Oţoiu's point, I would wish to place this tendency within the larger context of Romanian orthodoxy, in which words such as 'rosicrucian' or 'simoniac' are not culturally meaningful in Romanian, since the Orthodox Church has a different tradition (less centred on punishment and practices such as buying or selling ecclesiastical preferments) and cult objects. Nevertheless, suppressing the word 'catholic' cannot be construed in the same critical light, but it may suggest not only communist censorship but, through the translator's own background, almost unconsciously censoring a different religious ideology.

For communist propaganda, Stephen's rejection of the church for art, his repudiation of Catholic Ireland, the rebellion against Irish education and culture in A Portrait of the Artist as a Young Man were extremely convenient. Uncle Charles's definition of the Irish nation as "a priest-ridden Godforsaken race!" (35) (Ro.: Un neam dominat de preoţi şi uitat de Dumnezeu!) was just what the Romanians needed to read. The Catholic condemnation of Parnell, the Irish national hero, on grounds of lack of morality (Parnell had committed adultery) could be used very well by communist propaganda that resorted to similar methods to diminish anybody who dared criticize the government or the state. This is why, against expectations, against expecting to find long passages to either be toned down or to miss, one may be surprised to discover that all the dialogues between Dante, Mr. Casey, Simon Dedalus and Uncle Charles, the dreadful images of the Inferno in Stephen's imagination, are all faithfully preserved.

The Christmas dinner, so brimming with political agendas, lacks none of its original words in the Romanian version. Very minor, hardly significant changes appear ${ }^{11}$, yet they do not have any impact on the overall tone and fidelity of the translation.

\footnotetext{
${ }^{10}$ Yet Papadache translates "simony" as "simonie" in the first short story, Sisters [Surorile] in which it would have been impossible to avoid it, since the first person narrator comments on the strangeness of the word "paralysis" in connection with "gnomon in the Euclid and the word simony in the Catechism."

${ }^{11}$ Dante is already standing up ("stînd în picioare" -49), while in Joyce's text she is starting to her feet, Mr. Casey's short "Away with God" (36) is translated into something more literal and too long: "- Să se termine cu Dumnezeu" (49) (lit.: Let it be finished with God!), which sounds over-sophisticated in Romanian and is not direct enough. Mr Casey's general "I say!" becomes "vă spun" (lit.: I tell you).
} 


\title{
ROMANIAN HOS(TI)PITALITY IN TRANSLATING JOYCE
}

Biblical language is not only archaic but also formulaic. Joyce did use religious language in his book and the fragments referring to the Jesuit education Stephen pursued, the life in the school, the prayers and the sermons in church as well as to Stephen's private tribulations, are probably where one should look for Frida Papadache's best achievements in her rendering of Joyce's A Portrait. Yet, to a certain extent, they are both accomplished and flawed, as she constantly preserves the style of Romanian religious language, or yet makes Joyce's language sound more archaic than it is necessary. The translator almost enshrines Joyce's text in the textual formulae from the archetypal Book and also has a tendency to dramatize the narration to a higher extent than Joyce actually did.

For instance, a fragment such as

\begin{abstract}
We come from God, we live by God, we belong to God: we are His, inalienably His. God loves with a divine love every human soul, and every human soul lives in that love. How could it be otherwise? Every breath that we draw, every thought of our brain, every instant of life proceeds from God's inexhaustible goodness. (117)
\end{abstract}

is infused with archaisms in Romanian:

De la Dumnezeu venim, prin Dumnezeu trăim, lui Dumnezeu îi aparţinem; ai Lui sîntem, de-a pururi. Dumnezeu iubeşte cu dumnezeiască iubire fiece suflet omenesc şi fiece suflet omenesc trăieşte în această iubire. Cum ar putea fi altfel ? Orice suflare ce o tragem în piept, orice gînd al creierului nostru, orice clipă a vieţii purced din bunătatea neistovită a lui Dumnezeu. (172) (my italics)

With Ivănescu's translation of Ulysses, in 1984, when the simple act of going to church had become an act of courage for most Romanians, the situation is slightly different: many references to God either disappeared or were slightly transformed. Ivănescu's word "Dumnezeu" ("God") is repeated 183 times, while in Ulysses there are 293 occurences of the word. Many times Ivănescu replaces "Dumnezeu" with its synonym, "Doamne", equivalent of "Lord", which could be hoped to fool a less vigilant censorship, as it is also the plural of Romanian "doamnă" (lady) (see, for instance, U 1.51-52, Ulise, 14).

\section{Sexual Parts of Speech}

Papadache misses a series of "Joyce effects"12, as Derek Attridge called fragments such as the following:

\footnotetext{
Suck was a queer word. The fellow called Simon Moonan that name because Simon Moonan used to tie the prefect's false sleeves behind his back and the prefect used to let on to be angry. But the sound was ugly. Once he had washed his hands in the lavatory of the Wicklow Hotel and his father pulled the stopper up by the chain after and the dirty water went down through the

12 Joyce Effects is the title of Attridge's book in which he discusses the fragment 'Suck was a queer word' and analyses Joyce's language on sexuality in the episodes on Stephen's life as a schoolboy. (this peculiar interpretation is also published in Laurent Milesi's James Joyce and the Difference of Language. )
} 


\title{
ARLEEN IONESCU
}

hole in the basin. And when it had all gone down slowly the hole in the basin had made a sound like that: suck. Only louder. (4)

Attridge claims that the word "suck", which Stephen heard from a schoolboy at Clongowes Wood College ("You are McGlade's suck"), in spite of its meaning in the context (that of "favourite, sycophant"), would "evoke a realm of taboo sexuality" and would "possess for him an aura of the forbidden, the sinful, the unclean" (Attridge, 2000, 61). Papadache's choice for Joyce's potentially scabrous monosyllable "suck" is "giugiuc". She opts for this onomatopoeic word meaning nice, which comes from Turkish and is used through her own, arguably roundabout phonetic association with "ciubuc" (lolly pop), conveying the idea of sucking. Papadache syllabifies the word in "Şi cînd se scursese toată încet, gaura chiuvetei făcuse un zgomot ca ăsta: giu-giuc. Da' mai tare." (10), probably to compensate for her choice of a disyllabic word instead of a monosyllable which would have at least kept the suggestive force of the linguistics Joycean effect, if not the sexual one. If Stephen's theory (even false as it is) was that ugliness inheres in the sounds of a language, Papadache lost this effect as well, as "giugiuc" sounds more infantile and rather humourous.

Even Antoaneta Ralian's choice to translate "suck" in her 2012 translation, no longer censored, not only does not take into account Joyce's choice for the monosyllabic word, but transforms the noun into the adjective "lingău" (lit.: licker) and the sound corresponding to "suck" into the onomatopoeic "liingliing". It is rather odd why Ralian would attempt to make Joyce's text more literary and did not opt for the Romanian "sug" (monosyllabic and keeping the sexual connotation that the initial text suggested.

As previously shown in my analysis of Molly's monologue ${ }^{13}$, Ivănescu's translation of Ulysses had changed beyond recognition terms such as "fuck", "spunk", any references to the male sexual organ, or even a more biological (therefore technical) term like "menstruation". "Sex" as a noun and "sexual" as an adjective were also undesirable words, therefore Ivănescu had to resort to further trimming and re-styling. One of the best chapters that allowed him to conceal references was "Oxen of the Sun", in which diluting the meaning of words in old forms could provide a way of slipping past the censor's (in)attentive gaze. Thus, in a fragment like

\begin{abstract}
It grieved him plaguily, he said, to see the nuptial couch defrauded of its dearest pledges: and to reflect upon so many agreeable females with rich jointures, a prey to the vilest bonzes, who hide their flambeau under a bushel in an uncongenial cloister or lose their womanly bloom in the embraces of some unaccountable muskin when they might multiply the inlets of happiness, sacrificing the inestimable jewel of their sex when a hundred pretty fellows were at hand to caress, this, he assured them, made his heart weep. (U 12.672-679)
\end{abstract}

the sexual references are obfuscated by obsolete or archaic language that kept censorship busy and puzzled enough with terms that could no longer be found in dictionaries:

\footnotetext{
${ }^{13}$ In Scientia Traductionis, no. 8/2010 I compiled the list of sexual words that were cut or altered by Ivănescu in the translation of the last chapter of Ulysses.
} 


\title{
ROMANIAN HOS(TI)PITALITY IN TRANSLATING JOYCE
}

Îl ustura ca şi rana, zicea, să vază culcuşul nuntesc drămuit de cele mai dragi zăloage; şi să gîndească la atîtea femei de farmec pline şi cu mădularele podoabe, căzute pradă unor popi scîrbavnici, care îşi ascund flacăra sub obroc în vro mînăstire întunecoasă sau îşi rumpt floarea femeiască în labe de dihor puturos cînd ar putea aşa de bine să înmulţească cuibarele de fericiri, şi jertfinduşi scula de nepreţuit a părţii lor femeieşti cînd suta de voinici ar sta la îndemînă să o mîngîie, aceasta, le stătea el chezăşie, făcea inima lui să plîngă.(Ulise, 365 , my italics).

Miss Callan's description, "the amiable Miss Callan, who is the lustre of her own sex and the astonishment of ours?" $(U$ 12.829-830), is kept, with the transformation of "sex" into "secs" with a postposed article ${ }^{14}$ : "amabila doanzelă Callan, care sculă de preţ pentru secsul ei este şi mirarea celui al nostru" (Ulise, 369)

Ivănescu uses the right terminology in a fragment suffused with scientific terms:

\begin{abstract}
Must we accept the view of Empedocles of Trinacria that the right ovary (the postmenstrual period, assert others) is responsible for the birth of males or are the too long neglected spermatozoa or nemasperms the differentiating factors or is it, as most embryologists incline to opine, such as Culpepper, Spallanzani, Blumenbach, Lusk, Hertwig, Leopold and Valenti, a mixture of both? (U 12.1231-1236)
\end{abstract}

is translated as:

Trebuie să acceptăm părerea lui Empedocle din Trinacria că ovariul din dreapta (perioada de după scurgere, afirmă alţii) este răspunzător de naşterea băieţilor sau sînt spermatozoii prea multă vreme lăsaţi sau nemaspermele factorii divergenţi sau, cum embriologiştii cei mai mulţi se apleacă să-şi dea cu părerea, cum ar fi Culpepper, Spallanzani, Blumenbach Lusk, Hertwig, Leopold şi Valenti, este vorba de un amestec din amîndouă (Ulise, 378)

Ivănescu takes science as an excuse to use sexual terms without any surgical cut in Joyce's text, yet his working on the text is quite interesting, making the Romanian text sound more archaic than the English original. The translator uses the old form of the word ovary in Romanian: "ovariu", still used in medical treaties by the end of the nineteenth century, but replaced by the new form "ovar". "Postmenstrual period" is translated by Ivănescu not in scientific terms, but in colloquial language, "perioada de după scurgere" (lit.: the period after dripping; "scurgere" means "dripping" in Romanian and it would often replace the scientific word "menstruation": "menstruaţie" in oral speech). The Greek term "spermatozoon" (with its plural "spermatozoa") is no longer used in medical Romanian, but replaced by "spermatozoid" (with its plural "spermatozoizi"). Nevertheless, to keep as much as possible of the original, the Romanian translator uses the term "spermatozoii" which can be taken for either colloquial Romanian or may be uttered by a narrator who invents words in Romanian to sound more archaic. "Embriologişti" is also an old plural, no longer used in the eighties, having been replaced by "embriologi". The use of neologisms (like

\footnotetext{
14 "Secs" as a word in Romanian is a haplology.
} 


\section{ARLEEN IONESCU}

"factori divergenţi") alongside such archaic forms (or forms reinvented in order to sound archaic) results in a funny mixture.

In other contexts, the Circean discourse is shorn of some adjectives and Ivănescu skips "sex" in "I am the Virag who disclosed the Sex Secrets of Monks and Maidens" ( $U$ 15. 2546-2547): "Eu sînt Virag cel care-am dat în vileag secretele călugărilor şi fecioarelor." (Ulise, 438), as well as "sexsmelling" in "the old Royal stairs (for they love crushes, instinct of the herd, and the dark sexsmelling theatre unbridles vice), even a pricelist of their hosiery." ( $U$ 12. 33213322): "înghesuiala pe treptele Teatrului Regal, căci lor le place îmbulzeala, instinctele mulţimii şi semiîntunericul cu miros aţîţător din teatru lasă frîu liber viciului" (Ulise, 453). In spite of the symptomatic cuts, the Romanian text is not a colourless exchange, devoid of the irreverent tone of the narrator.

\section{Living On}

This essay was not intended in any way to provide an exhaustive account of all those passages inhos(ti)pitable to a faithful, literal as well as cultural translation, let alone in such a historically fraught ideological-political context as Romania. I will attempt to conclude this journey into a country whose bread and salt ${ }^{15}$ was not always a sign of welcoming the Other by returning to the Derridean thinking which has suggested the framing perspective for this article. In "Living On", Jacques Derrida - whose own essay titles ("Pas", "Fors", Glas, etc) often consciously defied the act of translation - imagined a commentary running below the main body of his text in which he ventures some remarks on translatability, a border line "to recognize within translatability, between two translations, one governed by the classical model of transportable univocality or of formalizable polysemy, and the other, which goes over the edge into dissemination - this line also passes between the critical and the deconstructive" (Derrida, 2010, 120-121). Originally commissioned for omnibus volume Deconstruction and Criticism, which sought to bring together the then Yale school (Harold Bloom, Paul de Man, Geoffrey Hartman, Hillis Miller, Jacques Derrida), "Living On" was Derrida's analysis of Shelley's poem The Triumph of Life. Derrida's choice was a double analysis: he made Shelley's text live on via Blanchot's ambiguously titled L'arret de mort ('Death Sentence' in the English translation; meaning at once "death sentence" and the "stoppage of/to death"). Wondering whether the poem lived on in or after Shelley's name, Derrida found a way of explaining life through death. Blanchot's récit L'arret de mort put in parallel two stories that do not touch each other, on two women who never met, one dying, the other living on. The one who lives on, Natalie, is herself a translator (Blanchot informs us that she translated from "all sort of languages", the predominant ones being German, English and Russian; for her the text is similar to what it was for both Blanchot and Derrida: an edge, a brink, a verge, a border, a boundary, a limit). The little we find out about Natalie is that she liked ac-

\footnotetext{
15 This is a traditional Slavic greeting ceremony, which was adopted by two non-Slavic nations, Lithuanians (Baltic) and Romanians (Latin), very close to their Slavic neighbours. It consists of presenting guests once they arrive on the threshold of their country with a tray/plate on which there is a loaf of bread and a salt holder or salt cellar. The guest is supposed to taste the bread and salt that the host offers him as a welcoming gesture.
} 


\section{ROMANIAN HOS(TI)PITALITY IN TRANSLATING JOYCE}

complishing her tasks, that she worked for the Ministry of Information, in a building with immense corridors. The book's story is set in France in 1938, therefore just before the war, and thus we could infer that Natalie's mission was to translate state documents in a very politically sensitive context. The first person narrator informs us that Natalie was disgusted by suicide. We can extend Natalie's horror of suicide to the death sentence passed on the translated text that does not comply with the demands of the original.

After the war, some thirthy years later, history repeated itself with a difference: on the other side of the Iron Curtain, other, similar buildings with immense corridors were built housing ministries with even more sombre purposes. One such building was the Romanian Security building, under whose roof information was selected. The only way to prevent texts from dying in communist Romania and to allow them to live on was to make translations pretend to tell something else (at least to the censors), while smuggling some of the originals' subversiveness into a border line sub-text. Joyce's translators encrypted the text in either archaic or formulaic language that would denounce an epoch whose abuses of all kinds were inhospitable.

As shown in the examples presented in this essay, there may be an economy that is at stake behind those cuts or omissions discussed above, an economy whereby the translator hopes to negotiate a political rite of passage for the original work to live on in translation rather than being stopped in its tracks (l'arrêt de mort). In spite of all kinds of sometimes necessary alterations and tamperings, Joyce's texts thus manage to live on.

Arleen Ionescu

arleen_ionescu@yahoo.com PhD, Professor, University of Ploieşti (UPG), Romania 


\section{ARLEEN IONESCU}

\section{Bibliography}

ATtRIDGE, Derek. Joyce Effects. On Language, Theory and History. Cambridge: Cambridge University Press, 2000.

"The Language, Sexuality and the Remainder in A Portrait of the Artist As A Young Man". In Milesi, Laurent (ed.), James Joyce and the Difference of Language, Cambridge: Cambridge University Press, 2003, 128-141.

Bamstone, Willis. The Poetics of Translation: History, Theory, Practice. New Haven and London: Yale University Press, 1993.

BENVENISTE, Emile. Le vocabulaire des institutions indo-europeennes. Paris: Minuit, 1969.

Blanchot, Maurice. Death Sentence. Lydia Davis (trans.). Barrytown, New York: Station Hill Press, 1988.

BLoom, Harold et. All, Deconstruction and Criticism, London and Henley : Routledge and Kegan Paul, 1979.

DERridA, Jacques. Hostipitality. In Angelaki, Journal of Theoretical Humanities, vol. 5, no. 3, 2000, 3-17.

Living On. In Parages. John Leavey (ed.). Stanford: Stanford University Press, 2010, 103-191.

DucA, Claudia Nedelcu. Despre literatură, comunism şi iubire cu Antoaneta Ralian, Interview with Antoaneta Ralian, 10 March 2010. In Flacăra, no. 3/ 2010, http://revistaflacara.ro/despre-literatura-comunism-si-iubirecu-antoaneta-ralian/, last accessed in October 2012.

DumitriU, Geta. Review of Ulise. In James Joyce Quaterly 35.1 (Fall 1997), 197-207.

IETA, Rodica. James Joyce's Ulysses in Romanian: an Uncanny and Foreign Language. In Joyce Studies in Italy, 10 (Joyce and/in Translation), Rosa Maria Bosinelli, Ira Torresi (eds.), Roma: Bulzoni, 2007, 119-133.

IONESCU, Arleen, Un-sexing Ulysses: The Romanian Translation "under" Communism. Scientia Traductionis, no. 8/2010.

JoyCE, James. Ulysses. A Critical and Synoptic Edition. Hans Walter Gabler (ed.), 3 vols., New York: Garland, 1986.

Ulise. Mircea Ivănescu (trans.). 2 vols., Bucureşti: Editura Univers, 1984.

Ulise. Mircea Ivănescu (trans.). Bucureşti: Editura Univers, Editura Fundaţiei Cultural Române, 1996. A Portrait of the Artist as a Young Man. Blackmask Online, 1999. Portret al artistului în tinereţe. Frida Papadache (trans.). Bucureşti: Ed. pentru Literatură Universală, 1969.

Portret al artistului în tinereţe. Frida Papadache (trans.). Bucureşti: Ed. Univers, 1987.

Portret al artistului în tinereţe. Antoaneta Ralian (trans.). Dana Crăciun (Preface). Bucureşti: Ed. Humanitas Fiction, 2012.

Dubliners. Blackmask Online, 1999.

Oameni din Dublin. Frida Papadache (trans.). Bucureşti: Ed. Pentru Literatură Universală, 1966. 


\section{ROMANIAN Hos(TI)PITALITY IN TRANSLATING JOYCE}

Oameni din Dublin. Radu Paraschivescu (trans.). Frida Papadache (trans.). Bucureşti: Ed. Humanitas Fiction, 2012.

KoHN, János. Romanian Tradition, In Mona Baker, Gabriela Saldanha (eds.). The Routledge Encyclopedia of Translation Studies. Oxford and New York: Routledge, 2009, 510-516.

NEGRICI, Eugen. Literatura română sub communism, vol. I, Bucharest: Editura Fundaţiei Pro, 2003.

O’NEILl, Patrick. Polyglot Joyce. Fictions of Translation. Toronto: University of Toronto Press, 2005.

OтоіU, Adrian. 'Le sens du pousser'. On the Spiral of Joyce's Reception in Romanian. In Geert Lernout and Wim Van Mierlo (eds.), The Reception of James Joyce in Europe, I. London and New York: Thoemmes Continuum, 2004. 198-213.

RALIAN, Antoaneta. Interview. In “Observatorul militar”. 25 May 2011, http://constantinpistea.wordpress.com/2011/05/26/, last accessed in October 2012.

Viaţa ca o carte (II). In Ziarul de Duminică, 20 April 2007, http://www.zf.ro/ziarul-de-duminica/antoaneta-ralian-ii-viata-ca-o-carte3031454, last accessed in October 2012.

RundLE, Christopher. Publishing Translations in Mussolini's Italy: A case Study of Arnoldo Mondadori. In Susan Bassnett, Rosa Maria Bollettieri Bosinelli and Margherita Ulrych (eds.). Textus. English Studies in Italy, Vol XII, No 2, (1999) Genova: Tilgher, 427-442.

ŞTEFÃNeSCU,. Ulysses in Romanian: The Secret Odyssey. In James Joyce Literary Supplement, vol 11. No. 1, Spring 1997, 15-16.

Tismãneanu, Vladimir. Stalinism for All Seasons: A Political History of Romanian Communism. Berkeley and Los Angeles: University of California Press, 2003.

TISMÃNEANU, Vladimir et all. Comisia prezidenţială pentru analiza dictaturii comuniste din România. Raport final, Bucureşti, 2006, http://www.presidency.ro/static/ordine/RAPORT_FINAL_CPADCR.pdf , last accessed in October 2012.

Venuti, Lawrence. Translation, Community, Utopia. In Lawrence Venuti (ed.). The Translation Studies Reader. New York and London: Routledge, 2002. 